\title{
RODZINNA POLITYKA DWUJĘZYCZNOŚCI W POLSCE NA WYBRANYM PRZYKLADZIE
}

\author{
AGNIESZKA STĘPKOWSKA
}

\section{Wstęp}

Pary dwujęzyczne w Polsce to zjawisko stosunkowo nowe. W ciągu ostatniej dekady, zwłaszcza po wstąpieniu Polski do Unii Europejskiej, par mieszanych przybyło. Choć same pary jak i rodziny dwujęzyczne występują w różnych kontekstach (np. Piller, 2002), to niewątpliwie kontekst polski można potraktować jako oryginalny element $\mathrm{w}$ ich opisie. Jeszcze do niedawna pary mieszane obywateli polskich i cudzoziemców znacznie częściej podejmowały decyzje o osiedleniu się poza Polską. Obecne ta tendencja nie jest już tak oczywista. Według sondażu przeprowadzonego w 2015 roku przez Centrum Badania Opinii Publicznej, połowa pytanych zna przynajmniej jednego cudzoziemca mieszkającego obecnie w Polsce. Natomiast aż dwie trzecie respondentów z największych polskich miast przyznało, że w gronie swoich znajomych ma cudzoziemca.

Główną przesłanką niniejszego artykułu jest założenie, że świadomie prowadzona polityka rodzinna par mieszanych językowo przynosi pożądane skutki w zakresie pełnej dwujęzyczności ich dzieci. Co więcej, dzieci wychowywane w parach dwujęzycznych mają duże szanse nie tylko na aktywne opanowanie języków obydwu rodziców, ale również z powodzeniem przechodzą procesy społecznej socjalizacji i kulturowej adaptacji. Społeczna socjalizacja polega na zrozumieniu kulturowych wzorców i językowych zachowań. W szczególności zaś, to właśnie doświadczenie społeczne umożliwia nabycie wiedzy językowej, pragmatycznej i kulturowej, które łącznie kształtują kompetencje komunikacyjne. W opinii Paula 
Garretta (2007: 233), socjalizacja językowa jest ,procesem rozwoju człowieka, zgodnie z którym dziecko lub inny przybysz (w dowolnym wieku) nabywa kompetencje komunikacyjne, które pozwalają na sensowne interakcje z innymi i na udział w życiu społecznym danej wspólnoty"1 (por. Garrett i Baquedano-López, 2002: 341).

Przedstawiony poniżej przykład rodziny dwujęzycznej skupia się na relacjach dotyczących codziennych praktyk komunikacyjnych mających na celu wychowanie dzieci w dwujęzyczności oraz do prawidłowego funkcjonowania w kulturach reprezentowanych przez obojga rodziców. Najważniejsze kwestie wspomnianych praktyk nawiązują do motywacji, osobistych doświadczeń oraz konsekwencji wynikających z przyjętej polityki językowej w obrębie dwujęzycznej rodziny. Wnioski zmierzają do podsumowania poziomu skuteczności wybranej strategii dwujęzyczności zastosowanej w przypadku wybranej rodziny.

\section{Dwujęzyczność: objaśnienie znaczenia}

Niniejsze rozważania opierać się będą na definicji dwujęzyczności sformułowanej przez Françoisa Grosjeana (2008: 10), który opisuje ją jako „regularne użycie dwóch lub więcej języków (lub dialektów)", natomiast osoby dwujęzyczne to takie, które „używają dwóch lub więcej języków (lub dialektów) w codziennym życiu”"2. Co więcej, Grosjean (2008) postuluje holistyczna perspektywe dwujęzyczności, według której osoba dwujęzyczna jest integralną całością, której nie da się podzielić na dwie osobne części. Innymi słowy, osoba dwujęzyczna nie jest sumą dwóch osób jednojęzycznych, ale raczej ma określoną i niepowtarzalną konfigurację językową. Ta całościowa perspektywa pozycjonuje osobę dwujęzyczną jako kompetentnego użytkownika języka z kompetencjami dopasowanymi do jego potrzeb. Grosjean (2008: 14) zauważa, że kompetencje komunikacyjne osób dwujęzycznych powinny być oceniane przez pryzmat ich całkowitych repertuarów językowych. Kompetencje komunikacyjne dwóch lub więcej języków rozwijają się w codziennym życiu w zależności od sytuacji i rozmówców. Korelacja między potrzebą językową a poziomem biegłości językowej ściśle się zazębia będąc jednocześnie zjawiskiem niestałym, podlegającym wpływom wielu czynników. Zależność tę określa się mianem zasady komplementarności, według której, im większa potrzeba, tym wyższy poziom umiejętności językowych (Grosjean, 2008: 243).

\footnotetext{
${ }^{1}$ Cytat w oryginale: "the human developmental process whereby a child or other novice (of any age) acquires communicative competence, enabling him or her to interact meaningfully with others and otherwise participate in the social life of a given community" (Garrett, 2007: 233).

${ }^{2}$ Cytat w oryginale: "Bilingualism is the regular use of two or more languages (or dialects), and bilinguals are those people who use two or more languages (or dialects) in their everyday lives" (Grosjean, 2008: 10).
} 
Trzeba też pamiętać, że dwujęzyczność pary nie jest równoznaczna z dwujęzycznością obydwu partnerów, choć przynajmniej jedno z nich musi używać języka partnera, lub oboje mogą korzystać z języka trzeciego. Indywidualny repertuar językowy jest też wynikiem motywacji do nauki języka partnera, pozycją lub znaczeniem języka partnera w hierarchii globalnego systemu językowego, a także ogólnej świadomości językowej danej pary oraz kwestii związanych z dwujęzycznością dzieci. Pary dwujęzyczne podejmują decyzje o własnych wzorcach komunikowania się. Decyzje te są także wyrazem ich językowych postaw oraz zróżnicowanych poziomów świadomości własnych zachowań komunikacyjnych. W większości przypadków pary mieszane stanowią zalążek określonego typu rodziny dwujęzycznej uzgadniając wspólnie dwujęzyczny rozwój swoich dzieci.

\section{Rodzina dwujęzyczna: wprowadzenie do studium przypadku}

Przykłady przeprowadzonych badań na temat dwujęzyczności w rodzinie (por. Lanza, 1990/2004) wzbudzają uzasadnione oczekiwania co do bogatego materiału jakościowego, skoncentrowanego na indywidualnych historiach życia w dwujęzyczności. Przypadek rodziny dwujęzycznej wybrany tutaj do analizy jest częścią większego badania jakościowego przeprowadzonego na parach dwujęzycznych zamieszkałych w Polsce. Struktura tematyczna wywiadu pogłębionego została zaplanowana tak, aby zebrać możliwie szeroki zakres relacji dotyczących różnych aspektów prywatnego kontaktu językowego, składających się na osobiste doświadczenia uczestników badania. Koncepcja badania ma na celu m.in. zgłębienie rodzinnej polityki dwujęzyczności prowadzonej wobec dzieci. Na bardziej szczegółowym poziomie, będzie to ustalenie źródeł informacji na temat dwujęzyczności dzieci i poziomu zaangażowania rodziców w dwujęzyczny proces wychowawczy oraz ocena konsekwencji, jakie wynikają z podejmowanych działań we wspomnianym zakresie. Badanie jest anonimowe, a imiona opisywanej pary zostały zmienione. Wywiad pogłębiony o zaplanowanej strukturze został nagrany, spisany $\mathrm{w}$ formie tekstu i zanalizowany m.in. przy pomocy najnowszej wersji oprogramowania do obróbki danych jakościowych (NVivo 11). Podjęta analiza korzysta z metodologii teorii ugruntowanej polegającej na podejściu indukcyjnym, generowanym przez nowe propozycje teoretyczne i hipotezy na podstawie zebranych danych (Glaser i Strauss, 1967).

Tematyka językowa nie jest na ogół uważana za osobistą i w sposób naturalny wzbudza zainteresowanie oraz chęć do zaangażowania się w rozmowę. Schemat wywiadu w połączeniu ze szczegółowymi pytaniami skierowanymi na rozbudowane odpowiedzi w praktyce przybrał formę naturalnej rozmowy z wybraną parą (por. Milroy i Gordon, 2003: 65). Uczestnicy badania byli świadomi swojej roli informatorów i byli przygotowani na poruszane przeze mnie wątki wywiadu. Podczas rozmowy przyjęłam pozycję ucznia, kogoś o mniejszym autorytecie od moich rozmów- 
ców, tym samym stosując „kontr-strategię socjolingwistycznego wywiadu”3 sugerowaną przez Williama Labova (1984: 40). Zaangażowanie emocjonalne moich rozmówców sprawiło, że mniej świadomie formułowali swoje wypowiedzi, skupiając się raczej na tym, co mówili a nie, jak się wypowiadali. Były to momenty, które dowodziły zasadności nie tylko sugestii poczynionej przez Labova, ale także całego podjętego przeze mnie badania jakościowego.

\section{Omówienie materiału badawczego}

\subsection{Metryka wybranej pary dwujęzycznej}

Para, z którą przeprowadziłam wywiad, to Polka i Hiszpan mieszkający w jednym z największych miast w Polsce, liczącym powyżej pięćset tysięcy mieszkańców. W momencie badania, przez ostatnich trzynaście lat para mieszkała w Polsce, natomiast oboje poznali się piętnaście lat temu. W codziennym życiu para posługuje się $\mathrm{w}$ domu językiem hiszpańskim i jest aktywnie zaangażowana w dwujęzyczne wychowanie dwojga dzieci w wieku 10 i 4 lata. Poniżej, Tabela 1 ujmuje najważniejsze informacje wstępne dotyczące wybranej pary:

Tabela 1. Podstawowe informacje na temat pary dwujęzycznej wybranej do analizy.

\begin{tabular}{|c|c|c|c|c|c|c|}
\hline $\begin{array}{c}\text { Partner } \\
\text { polski } \\
\text { (wiek) }\end{array}$ & $\begin{array}{c}\text { Partner } \\
\text { cudzoziemiec } \\
\text { (wiek) }\end{array}$ & $\begin{array}{c}\text { Narodowość } \\
\text { partnera } \\
\text { cudzoziemca }\end{array}$ & $\begin{array}{c}\text { Lata } \\
\text { razem }\end{array}$ & $\begin{array}{c}\text { Lata } \\
\text { w Polsce }\end{array}$ & Język pary & $\begin{array}{c}\text { Dzieci } \\
\text { (wiek) }\end{array}$ \\
\hline Maria (42) & Felipe (37) & hiszpańska & 15 & 13 & hiszpański & $2(10,4)$ \\
\hline
\end{tabular}

W przypadku Marii i Felipe od samego początku znajomości ich komunikacja nie była problemem, gdyż w momencie poznania Maria była już absolwentką filologii hiszpańskiej. Obecnie, po ponad dekadzie w Polsce, Felipe potrafi porozumiewać się po polsku, choć nadal zmaga się z polską gramatyką i wymową, uznając polską pisownię za barierę nie do pokonania. Kwesta opanowania języka partnera prowadzi też do pytań o znajomość innych języków w parze dwujęzycznej. Pominąwszy język hiszpański w przypadku Marii, opanowanie pozostałych języków u obojga partnerów plasuje się w okolicach poziomu średniego zaawansowania, nie przekraczając poziomu B2. Felipe uczył się angielskiego jako pierwszego języka obcego, a następnie francuskiego i w końcu polskiego. Wszystkie jego języki mieszczą się w granicach między B1 i B2. Z kolei Maria, po opanowaniu hiszpańskiego, zabrała się za naukę języka angielskiego, którą ukończyła na poziomie B2. Ponadto, do swojego

\footnotetext{
${ }^{3}$ Cytat w oryginale: "counter-strategy of the sociolinguistic interview" (Labov, 1984: 40).
} 
repertuaru językowego zalicza ona jeszcze francuski oraz rosyjski i łacinę, czyli języki bardziej zapamiętane z zajęć szkolnych, aniżeli faktycznie opanowane. Stąd też ich poziom u Marii można uznać za bardzo podstawowy. Poniżej, Tabela 2 ilustruje repertuary językowe zarówno Marii jak i Felipe.

Tabela 2. Repertuary językowe omawianej pary dwujęzycznej.

\begin{tabular}{|c|l|c|c|c|}
\hline \multirow{2}{*}{ Para } & \multirow{2}{*}{ Język ojczysty } & \multicolumn{3}{|c|}{ Poziom wiedzy językowej na podstawie samooceny } \\
\cline { 3 - 5 } & & $\mathrm{C} 1 / \mathrm{C} 2$ & $\mathrm{~B} 1 / \mathrm{B} 2$ & A1 / A2 \\
\hline \multirow{2}{*}{ Maria } & polski & hiszpański & angielski & francuski, rosyjski, łacina \\
\cline { 2 - 5 } Felipe & hiszpański & - & angielski, francuski, polski & - \\
\hline
\end{tabular}

W kontekście repertuarów językowych, warto też zwrócić uwagę na angielski ze względu na jego globalną pozycję oraz na fakt, iż jest to najpopularniejszy język obcy nauczany w Europie i w wielu innych miejscach świata. Bezprecedensowe rozprzestrzenienie się angielskiego stanowi główną motywację do nauki wielu ludzi na całym świecie, co skutkuje zjawiskiem, które można określić jako wielojęzyczność z angielskim (por. Aronin i Singleton, 2008: 3). Jak widać w Tabeli 2, omawiana para wymienia angielski na pierwszym (w przypadku Felipe) i na drugim miejscu (w przypadku Marii). Nic też dziwnego, że niezależnie od innego języka partnera, potrzeba znajomości angielskiego jest przez obojga doceniana $\mathrm{w}$ równym stopniu, zarówno w odniesieniu do siebie, jak i do dzieci.

\subsection{Prywatna polityka dwujęzyczności w rodzinie}

\subsubsection{Sposoby nabywania dwujęzyczności przez dzieci}

Pojęcie dwujęzyczności w rodzinie, lub też dwujęzyczność rodziny (family bilingualism), które przyjęłam za Elizabeth Lanzą (2007: 46), odnosi się do dwujęzyczności indywidualnej w rodzinie. Dla porównania, wspomniany wyżej Grosjean (2010: 205) postuluje szerszy zakres koncepcji 'rodzina' i włącza do niego również dziadków i dalszych członków rodziny, a nawet opiekunów. Niemniej, bliższy ogląd rodziny (tzn. rodzice i dzieci) daje możliwość zgłębienia kwestii, które sprzyjają dwujęzyczności w przypadkach takich jak w Polsce, gdzie język mniejszościowy nie uzyskuje wsparcia ze strony społeczności większościowej w odróżnieniu od kontekstów dwujęzycznych na poziomie społeczeństwa. Nabywanie języków przez dzieci w rodzinie może różnić się liczbą i kombinacją językową, ale zazwyczaj odbywa się w jednym z dwóch trybów: symultanicznym lub sekwencyjnym (por. Paradis, 2007). 
I tak, dwujęzyczność symultaniczna, zwana też równoczesną albo współrzędną, zachodzi wtedy, gdy każde z rodziców mówi do dziecka w innym lub swoim ojczystym języku, np. ojciec mówi po hiszpańsku, a matka po polsku. Uważa się, że drugi język powinien zostać wprowadzony przynajmniej przed ukończeniem trzeciego roku życia przez dziecko. Według Grosjeana (2010: 178), ten typ dwujęzyczności dotyczy mniej niż 20 procent dwujęzycznych dzieci, a zatem występuje rzadziej niż dwujęzyczność sekwencyjna. Większość dzieci staje się dwujęzyczna właśnie w sposób sekwencyjny, zwany też dwujęzycznością sukcesywną albo podporządkowaną. Oznacza to, że dziecko uczy się pierwszego języka w domu, a następnie drugiego języka w szkole lub w społeczności, z którą ma do czynienia poza domem. Innymi słowy, język drugi nabywany jest przez dziecko jako kolejny, kiedy już wcześniej posługuje się ono językiem obojga rodziców, lub którym mówi się w domu. Sekwencyjny rodzaj dwujęzyczności skutkuje często tym, że dziecko może opanować język kraju przyjmującego lepiej aniżeli rodzice, co nie pozostaje bez wpływu na wzajemne relacje rodziców i dzieci. Opanowanie drugiego języka będącego językiem społeczności pozwala dziecku na identyfikowanie się ze społecznością, w której funkcjonuje.

\subsubsection{Rodzinna polityka językowa: język mniejszości w domu}

Każda para dwujęzyczna staje przed językowym dylematem w kontekście wychowywania dzieci. Należy przy tym pamiętać, że takie pary różnią się świadomością językową, znajomością języków i determinacją w przekazywaniu dwujęzyczności swoim dzieciom. W swoich próbach nakierowanych na wyjaśnienie zróżnicowań w przyswajaniu języków przez dwujęzyczne dzieci, uczeni w sposób szczególny przyjrzeli się wzorcom czy też schematom użycia języków w domu. W oparciu o typologię opisaną przez Edith Harding i Philipa Riley (1986), Suzanne Romaine (1999: 64) zaproponowała sześć typów wyborów językowych w rodzinie, które różnią się m.in. ojczystymi językami rodziców, językiem lub językami danej społeczności, oraz strategią stosowaną przez rodziców wobec dzieci.

Każda strategia w nieco inny sposób promuje dwujęzyczność wśród dzieci, dlatego warto pokrótce je nakreślić. Strategia pierwsza, 'jeden rodzic - jeden język', jest bodaj najpopularniejsza $w$ małżeństwach mieszanych, kiedy każde $\mathrm{z}$ rodziców używa swojego języka ojczystego w kontakcie z dzieckiem, ale też do pewnego stopnia znając język współmałżonka. Strategia druga, 'język mniejszości w domu', to przypadek, w którym małżonkowie mają różne języki ojczyste, ale oboje zwracają się do dziecka w języku mniejszości, wiedząc, że dziecko styka się z językiem większości poza domem. Strategia trzecia, 'język mniejszości w domu bez wsparcia społeczności', występuje kiedy rodzice mówią do dziecka tym samym językiem ojczystym, a język dominujący nie jest językiem rodziców. W strategii czwartej, 
'podwójny język mniejszości w domu bez wsparcia społeczności', rodzice mają różne języki ojczyste, ale język dominujący społeczności nie jest językiem żadnego z rodziców. W strategii piątej, ‘język obcy rodziców', jedno z rodziców zawsze zwraca się do dziecka w języku obcym, mimo że oboje rodzice mają ten sam język ojczysty, a język dominujący jest również ich językiem. Ostatnia strategia, 'języki mieszane', dotyczy dwujęzycznych rodziców, którzy zmieniają i mieszają języki w kontakcie z dziećmi.

Niektóre z przedstawionych $\mathrm{w}$ tym krótkim zarysie strategii wiążą się z określonym typem dwujęzyczności u dzieci. Dla przykładu, strategia 'jeden rodzic - jeden język' oznacza wprowadzenie dwujęzyczności symultanicznej, podczas gdy strategie, wedle których językiem mniejszościowym mówi się w domu, promują raczej dwujęzyczność sekwencyjną. Co więcej, Suzanne Quay (2001) nie wyklucza również, że obydwa typy dwujęzyczności zdarzyć się mogą jednocześnie tam, gdzie dziecko ma dwa języki w domu, a później kolejnym językiem posługuje się poza domem.

Wybrany do analizy przykład pary hiszpańsko-polskiej reprezentuje strategię ‘języka mniejszości w domu’. Według tej strategii, oboje rodzice mówią w języku mniejszościowym, czyli po hiszpańsku, języku ojczystym Felipe (Fragm. 1). Język dominujący, polski, jest językiem ojczystym Marii. Zatem, język dominujący jest językiem szerszej społeczności, natomiast drugi język - hiszpański - nie jest używany przez tę społeczność (por. Lanza, 2007: 46). Tabela 3 zawiera syntetyczny opis strategii z użyciem języka mniejszości w domu w formie podsumowania dla omawianego tutaj przykładu rodzinnej polityki dwujęzyczności.

Tabela 3. Wybrany przykład strategii stosowany przez rodzinę wychowującą dzieci w dwujęzyczności na podstawie typologii opracowanej przez Suzanne Romaine (1999; 2008)

\begin{tabular}{|l|l|l|l|}
\hline \multicolumn{1}{|c|}{ Typ } & \multicolumn{1}{|c|}{ Rodzice } & \multicolumn{1}{c|}{ Społeczność } & \multicolumn{1}{c|}{ Strategia } \\
\hline $\begin{array}{l}\text { język mniejszości } \\
\text { w domu (non-do- } \\
\text { minant home lan- } \\
\text { guage) }\end{array}$ & $\begin{array}{l}\text { mają różne języki } \\
\text { ojczyste }\end{array}$ & $\begin{array}{l}\text { język jednego z ro- } \\
\text { dziców jest domi- } \\
\text { nującym językiem } \\
\text { w społeczności }\end{array}$ & $\begin{array}{l}\text { oboje rodzice mówią językiem mniej- } \\
\text { wystawione dziecka, które jest wa pełni } \\
\text { dominującym jedynie poza domem }\end{array}$ \\
\hline
\end{tabular}

Maria i Felipe rozmawiają z dziećmi po hiszpańsku i dotyczy to nie tylko sytuacji w domu, ale również każdej innej scenerii, w której rodzice znajdują się sami z dziećmi (1. 15-19). Ciekawym faktem do odnotowania jest to, że dzieci między sobą porozumiewają się wyłącznie po polsku (1. 6-9), czyli w języku dominującym poza domem. Kombinacje językowe zmieniają się również w kontakcie matki z czteroletnią córką (1. 21-30), która jest na etapie mieszania języków (1. 13-14). 
Fragment 1: „W domu jest hiszpański”

1 Badaczka Czyli wy macie taką strategię, że w domu jest

2 jeden język, a poza domem jest inny język?

3 Maria Też nie. W domu jest hiszpański...

4 Badaczka W ogóle ze wszystkimi? Wszyscy mówią po

$5 \quad$ hiszpańsku? Dzieci też?

6 Maria Nie. Dzieci między sobą nigdy nie mówią

$7 \quad$ po hiszpańsku.

8 Badaczka Dzieci mówią po polsku?

9 Maria Mówią po polsku.

10 Felipe Czasami ja powiem Arturowi, że on musi po

11 hiszpańsku porozmawiać z małą, bo mała już teraz...

12 Maria Z Sarą.

13 Felipe Bo Sara teraz cały czas mówi po polsku, i mówi

14 po hiszpańsku.

15 Maria To znaczy my w domu mówimy płynnie. Kiedy

16 się spotykamy przy kolacji czy innych posiłkach

17 czy w weekend, gdy czas spędzamy razem, to

18 mówimy po hiszpańsku między sobą, czyli jak

19 jesteśmy gdzieś w czwórkę.

20 Badaczka Ale dzieci też?

21 Maria Tak, tak. Ale na przykład kiedy ja sama jestem z

22 córką i ona chce ze mną grać w coś, to wtedy gramy

23 po polsku, rozmawiamy po polsku, bawimy się po

24 polsku. Zdarza się, że na przykład mamy domino to

25 mówię, choć zrobimy to po hiszpańsku, jakoś tam

26 powtórzymy, to ona nie do końca chce. Ale to myślę,

$27 \quad$ że to może wypływa $\mathrm{z}$ tego, że tu bardziej jako

28 nauczycielka podchodzę do tego i żeby sobie

29 przypomnieć jakieś słówka czy poszerzyć. Bo

30 ona jeszcze słabo mówi po hiszpańsku.

Charakterystyczne dla tej strategii jest to, że jest ona popularnym modelem funkcjonowania dla rodzin żyjących na emigracji. Rodziny te często używają pierwszego języka rodziców w domu, czyli języka mniejszości, podczas gdy dzieci poza domem i w trakcie edukacji szkolnej nabywają kolejny język, będący językiem większości, czyli społeczeństwa, w którym dana rodzina decyduje się żyć. Momentem przełomowym jest pójście dzieci do szkoły. Wówczas proporcje wystawienia na kontakt z obydwoma językami u tych dzieci stopniowo zmieniają się na korzyść języka dominującego, który za ich pośrednictwem zaczyna pojawiać się również w domu. Wtedy wyzwaniem dla rodziców staje się dalsze utrzymanie ich języka ojczystego w kontakcie $\mathrm{z}$ dziećmi, by te zbyt łatwo i nieświadomie nie przeszły wyłącznie na język większości. 


\subsubsection{Zaangażowanie w dwujęzyczność dzieci}

Wychowanie dwujęzyczne stanowi nie lada wyczyn, jako że wymaga nie tylko podjęcia decyzji, ale przede wszystkim zaangażowania $\mathrm{w}$ realizację powziętego zadania. Sądząc po wysokim stopniu dwujęzyczności osiągniętej przez dzieci Marii i Felipe, można powiedzieć, że para odniosła w tym zakresie sukces. Oboje od początku mówią do dzieci po hiszpańsku, w wyniku czego dzieci mają aktywną znajomość hiszpańskiego i polskiego. Dzieci są w wieku 10 i 4 lat i już zdają sobie sprawę z różnych języków ojczystych swoich rodziców. Maria ma świadomość, że w przyszłości może będzie musiała zorganizować dzieciom lekcje hiszpańskiego, gdyż słusznie spodziewa się, że z biegiem lat język polski u dzieci stanie się silniejszy (Fragm. 2). Prawdopodobnie mówienie po hiszpańsku w domu nie wystarczy, by utrzymać językową równowagę. Obawy te sprawiają, że Maria wysyła swojego 10-letniego syna na dwumiesięczne wakacje do jego dziadków w Hiszpanii, by jego hiszpański odzyskał rodzimą biegłość po całym roku szkolnym spędzonym w Polsce (1. 5-9). Maria relacjonuje to w ten sposób:

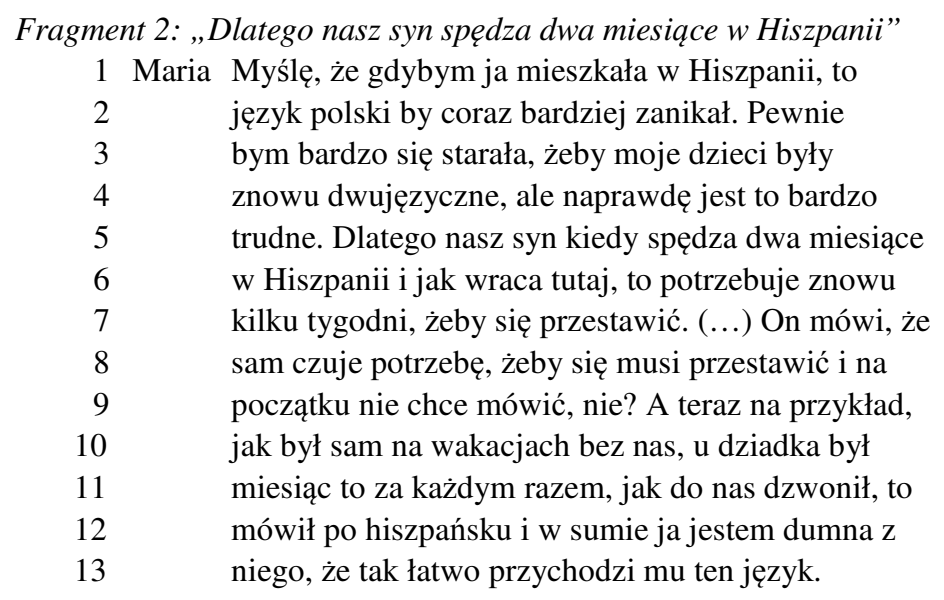

Dla Marii mąż Hiszpan stanowi praktyczne wsparcie i wzbogacenie językowe dla niej samej jako nauczycielki hiszpańskiego. Natomiast w swoich różnych językach ojczystych oboje widzą potencjał do wykorzystania przede wszystkim w procesie wychowywania dzieci (Fragm. 3). Myśl o zmarnowaniu takiej szansy jest dla nich nie do zaakceptowania (1. 4-8). Dlatego też, wykazują się dużą determinacją w doprowadzeniu dzieci do pełnej dwujęzyczności, wzmocnioną negatywnym przykładem, o którym Maria opowiada tak:

Fragment 3: „Nie dopuścimy do tego, żeby nasze dzieci znały tylko jeden język”

1 Maria Faktycznie chodziło o dzieci, bo poznaliśmy takie

2 małżeństwo polsko-palestyńskie. Nasz dentysta był 


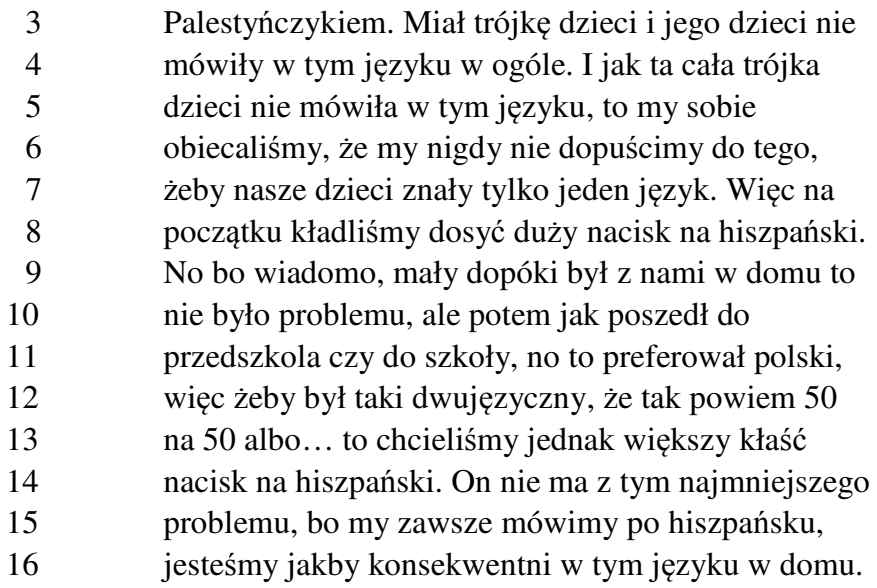

Zaangażowanie rodziców $\mathrm{w}$ proces wychowywania dzieci w dwujęzyczności obejmuje też bardzo istotny etap przygotowania dzieci do dwujęzycznej formy funkcjonowania z szerszym otoczeniem poza rodziną (Fragm. 4). Przygotowanie to polega na uświadomieniu dzieciom ich sytuacji językowej, znajomości języków, możliwości związanych $\mathrm{z}$ tą wiedzą oraz sposobach radzenia sobie $\mathrm{z}$ ewentualnym brakiem zrozumienia wśród rówieśników (1. 4-9, 24-33). Dla dzieci w wieku szkolnym jakakolwiek forma wyróżniania się traktowana jest jako pewnego rodzaju obciążenie, czy też „inność”, która przeszkadza a nie pomaga. Dzieci dwujęzyczne niejednokrotnie próbują ukrywać ten fakt o sobie, co prowadzi do zamykania się w sobie na kontakt zewnętrzny. Dodatkowym i znacznie poważniejszym problemem jest odmienność wynikająca $\mathrm{z}$ innej rasy. Wówczas wygląd może stać się swego rodzaju stygmatem, szczególnie boleśnie odczuwanym przez dzieci (1. 12-19). Zbierając doświadczenia i zapoznając się też z przypadkami innych par mieszanych językowo, Maria i Felipe włożyli wiele wysiłku w przygotowanie syna do radzenia sobie ze wszystkimi efektami ubocznymi wynikającymi zarówno ze znajomości drugiego języka, jak i nietypowego wyglądu.

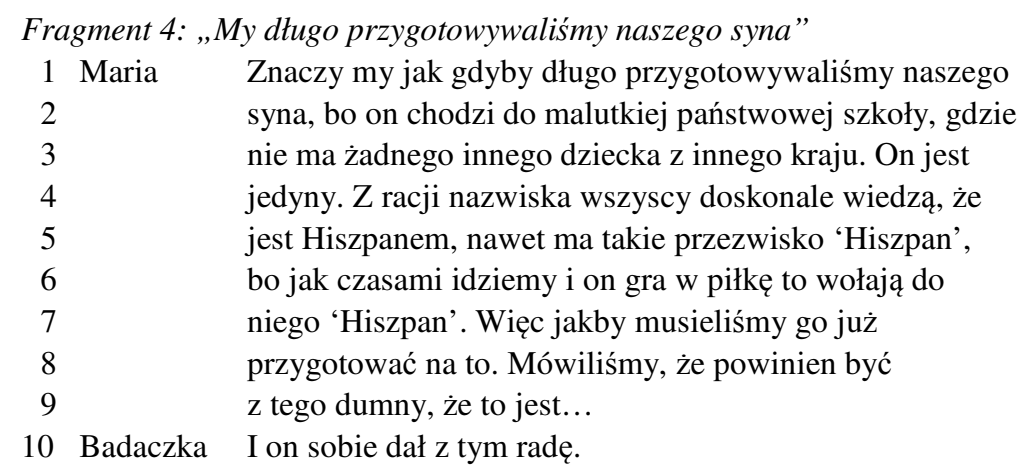


11 Maria Oczywiście. To nie jest dla niego powód do...

16 Badaczka

17 Maria coś negatywnego. Natomiast mamy też znajomą z

Badaczka Japonii i ona ma dwójkę dzieci, dwóch synów. No oczywiście te dzieci mają skośne oczy i z tego powodu dzieci wyśmiewają się z nich.

\section{Mowi, ze jak je odwoz}

Wyglądają inaczej.

(1)

Mówi, że jak je odwozi rano do szkoły, to tam pokazują czy się wyśmiewają i jej jest z tego powodu bardzo przykro. Jak oni sobie z tym radzą, tego nie wiem.

\begin{tabular}{|c|c|}
\hline & $\begin{array}{l}\text { Natomiast my to wszystko chłoniemy co nam mówią inni } \\
\text { doświadczenia i mi się wydaje, że to jest cenniejsze niż }\end{array}$ \\
\hline & książki i staramy się jakby... \\
\hline Badaczka & ...żeby dzieciom pomóc. \\
\hline Maria & $\begin{array}{l}\text { Tak, żeby uprzedzić takie sytuacje i już podbudować, bo } \\
\text { jeżeli mój syn idzie do szkoły nowej i wie... znaczy jest }\end{array}$ \\
\hline & $\begin{array}{l}\text { przygotowany na to, co go może spotkac, to jest inaczej } \\
\text { niż kiedy to będzie kompletne zaskoczenie. Bo ktoś może }\end{array}$ \\
\hline & powiedzieć 'Hiszpan' na zasadzie... \\
\hline Badaczka & ....̇artu. \\
\hline Maria & Albo po prostu jak każde inne nazwisko. A może \\
\hline & powiedzieć w sensie negatywnym, tak jak może \\
\hline & powiedzieć 'czarnuch' czy nie wiem 'brudas', \\
\hline & 'Arab' czy cokolwiek... \\
\hline Badaczka & To już jest obraźliwe. \\
\hline Maria & Tak, pejoratywne. \\
\hline
\end{tabular}

\subsubsection{Ocena wyników rodzinnej polityki dwujęzyczności dzieci}

Zarówno znajomość języka jak i postawy językowe nabywane są w procesie wychowawczym przez dzieci od rodziców, oraz od członków dalszej rodziny, rówieśników i wychowawców szkolnych. Dlatego ważne jest, aby sytuacja dwujęzyczności kształtowała w dzieciach i rodzicach postawę otwartości i akceptacji dla siebie i dla innych. Wówczas możliwy jest szerszy obraz świata, dzięki któremu łatwiej o szacunek dla nowych kultur i o wzbogacenie emocjonalne. Jednym z najważniejszych czynników wpływających na rozwój wczesnej dwujęzyczności u dzieci są nie tylko wybory językowe dokonywane przez rodziców, ale także ich sposób interakcji z dziećmi (por. De Houwer, 1999). Naturalnie, językowe zachowania rodziców względem dzieci są bardzo zróżnicowane i można je brać za bezpośredni skutek przekonań i opinii rodziców, np. co do tego, jak dzieci mają przyswoić sobie język i roli rodziców w tym procesie, a także postaw rodziców wobec języków i wobec dwujęzyczności w ogóle, oraz konkretnych wzorców wyborów językowych 
(De Houwer, 1999: 81). W związku z tym, w niniejszym artykule założyłam, że postawy i przekonania rodziców odnośnie rozwoju językowego dzieci są częścią bardziej ogólnych postaw oraz że zapatrywania rodziców na całościowy rozwój ich dzieci są różne. Poniżej, Fragment 5 prezentuje stosunek Marii i Felipe do różnorodności językowej i kulturowej. Maria mówi o własnym małżeństwie, że jest „dwunarodowe” (1. 1) niejako uzasadniając otwartość własną i męża na sprawy bardziej ogólne, takie jak np. przyjmowanie uchodźców z krajów objętych wojną (1. 4-6). Z wypowiedzi Marii i Felipe zgodnie wynika, że kluczem do postawy otwartości jest poznanie języka i kultury innych narodowości (1. 11-18).

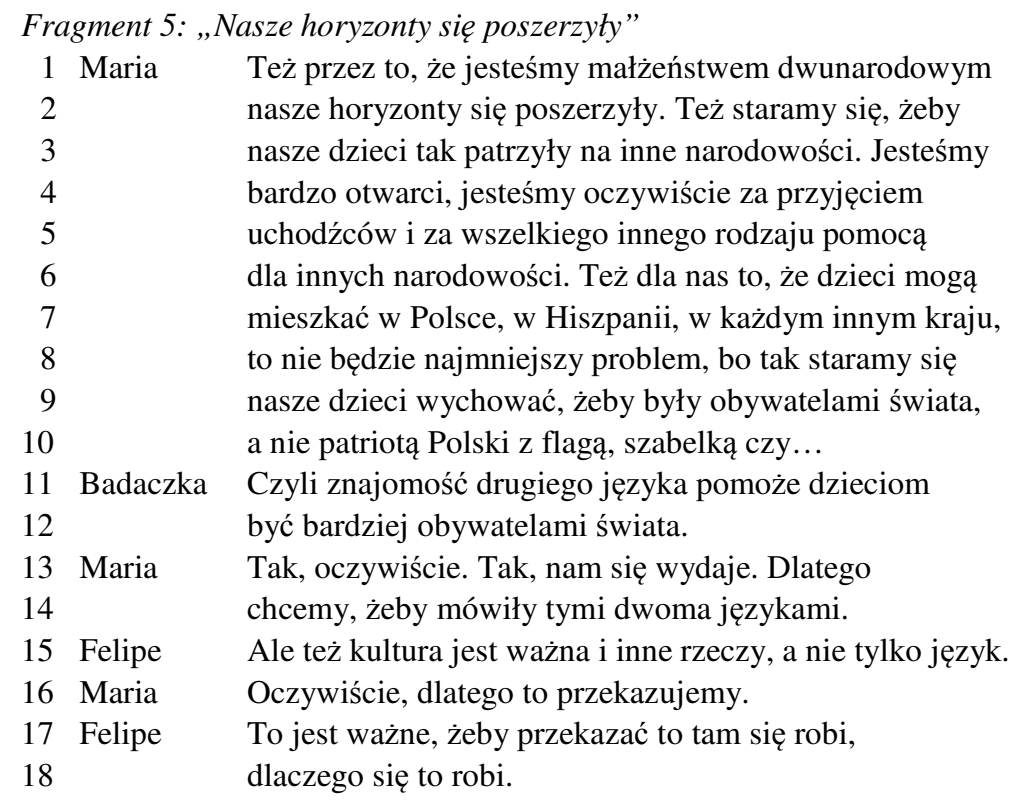

Zatem widać, że oczekiwania wobec dzieci z mieszanych małżeństw są obecne i dotyczą umiejętności nabycia i rozróżniania istotnych cech charakterystycznych dla obydwu kultur reprezentowanych przez rodziców (por. Lambert, 1977: 20). Rodzice w analizowanej parze dwujęzycznej nie tylko wyrażają pozytywne poglądy na temat dwujęzyczności swoich dzieci, ale także podejmują określone działania i świadomie realizują wcześniej obrane językowe zachowania wobec sowich dzieci, polegające przede wszystkim na używaniu języka mniejszościowego w domu. Strategia ta już przyniosła oczekiwane skutki, choć proces nabywania przez dzieci dwóch języków nadal trwa (w przypadku ich 10-letniego syna), lub też dopiero co się rozpoczął (w odniesieniu do ich 4-letniej córki). Przypadek syna ilustruje Fragment 6, poniżej. Maria obserwuje językowe postępy syna, które ją zadowalają (1. 3), choć przyznaje, że synowi zdarza się jeszcze mieszanie języków (1. 8-12). 
Fragment 6: „Syn po polsku mówi lepiej niż ja”.

1 Badaczka Ale syn po polsku mówi...

2 Felipe No mówi lepiej niż ja. (śmiech)

3 Maria Oczywiście, że lepiej. No chodzi do szkoły,

4 pisze dyktanda, ale preferuje...

5 Badaczka To znaczy, jak mówi, to tak jakby Polak mówił.

6 Felipe Tak, tak.

7 Maria To znaczy, nie ma akcentu, może dlatego, że

8 nigdy tam [w Hiszpanii] nie mieszkał. Miesza

9 słowa czy wstawia jak nie zna. Jak mówi i zależy

10 mu na szybkości, żeby powiedzieć, to wstawia

11 słowa hiszpańskie z polską końcówką, czasowniki,

12 których na przykład nie ma w języku polskim.

W przypadku córki tej pary, sytuacja jest trochę inna niż z synem. Dziewczynka jest jeszcze mała, bo ma dopiero 4 lata, więc na tym etapie jej ogólnego rozwoju trudno mówić o w pełni wykształconej dwujęzyczności. Obecnie dziewczynka jest bardziej skłonna mówić po polsku, bo ma więcej kontaktu z tym językiem (1. 1-2). Maria śledzi ten proces i tłumaczy również, z czego wynika takie zachowanie córki (1. 2-9).

Fragment 7: „My na pewno będziemy konsekwentni”

$\begin{array}{rll}1 & \text { Maria } & \text { Ona... No czasami jest trochę oporna, nie do końca } \\ 2 & & \text { chce. Woli mówić po polsku. Też jest trochę inna } \\ 3 & & \text { sytuacja, że jednak ja dużo więcej pracowałam, kiedy } \\ 4 & & \text { się urodził Artur i Felipe z nim był więcej. Natomiast } \\ 5 & & \text { ja z Sarą spędzam więcej czasu, bo teraz on więcej } \\ 6 & & \text { pracuje niż ja i ona ma więcej polskiego i w przedszkolu } \\ 7 & & \text { i ze mną w domu. Więc jakby ten hiszpański nie ma } \\ 8 & & \text { w tej chwili równego układu w domu. Ma jednak } \\ 9 & & \text { więcej kontaktu z polskim. Czasami nie chce. } \\ 10 & \text { Badaczka } & \text { Ale w sumie wasza strategia działa, to znaczy na } \\ 11 & & \text { dzieci dobrze działa. Na przykład, mówię o waszym } \\ 12 & & \text { synu. Generalnie ta dwujęzyczność jakby wychodzi. } \\ 13 & \text { Felipe } & \text { Tak. } \\ 14 & \text { Maria } & \text { Tak. } \\ 15 & \text { Badaczka } & \text { To działa. I tak samo pewnie wyjdzie wam z córką. } \\ 16 & \text { Maria } & \text { Pewnie tak. Znaczy, my na pewno będziemy konsekwentni. }\end{array}$

Zatem widać, że motywacja i determinacja rodziców w doprowadzeniu dzieci do dwujęzyczności jest ważna (1. 16) i powiązana z użyciem języka poza domem i poza relacją rodzic-dziecko (1. 6-9). Ta determinacja u rodziców zależy też od stopnia poczucia czy też faktycznego wyizolowania bądź adaptacji ich dwujęzycznej rodziny w jednojęzycznym społeczeństwie polskim, w którym przyszło im żyć. 


\section{Podsumowanie}

Podjęte studium przypadku dwujęzycznej rodziny w Polsce zostało przedstawione z perspektywy socjologii języka, która pozwoliła uwidocznić metajęzykową świadomość tej pary oraz jej indywidualne doświadczenia związane z rodzinną polityką dwujęzyczności wobec dzieci. Analizowana para Polki i Hiszpana przyjęła strategię komunikacji określaną jako ‘język mniejszości w domu’, według której cała rodzina mówi ze sobą po hiszpańsku. Dotychczasowa praktyka tej pary w tym zakresie przyniosła spodziewane dobre rezultaty, szczególnie widoczne na przykładzie ich 10-letniego syna. Ponadto, z powyższego omówienia wybranych fragmentów wywiadu pogłębionego $\mathrm{z}$ tą parą dwujęzyczną, można również wyprowadzić kilka uogólnionych wniosków:

- sytuacja rodziny dwujęzycznej, w której panuje pozytywne nastawienie do dwujęzyczności oraz silne przekonanie o roli sprawczej rodziców wobec dzieci w tym zakresie, stanowi wystarczające wsparcie dla zaistnienia aktywnej dwujęzyczności na wczesnym etapie rozwoju dzieci;

- postawy wobec języka i jego użytkowników, a także motywacja językowa, stanowią podstawowe czynniki w podtrzymaniu języka i w określonych zachowaniach językowych;

- wychowanie dwujęzyczne dzieci w przekonaniu rodziców poszerza horyzonty i zmienia dzieci w obywateli świata, otwartych i pozbawionych uprzedzeń wobec osób innych narodowości;

- u par dwujęzycznych występuje wyższy poziom świadomości językowej związanej z językową przyszłością ich dzieci;

- na ogół pary dwujęzyczne wiedzą, jak wychowywać dzieci w dwujęzyczności i w ramach jasno przyjętej strategii językowej polityki rodzinnej odnoszą w dużej mierze sukces.

\section{Literatura}

Aronin, L. i D. Singleton. 2008. „Multilingualism as a new linguistic dispensation”. International Journal of Multilingualism 5. 1-16.

De Houver, A. 1999. „Environmental factors in early bilingual development: the role of parental beliefs and attitudes". W zbiorze: Extra, G. i L. Verhoeven (red.) Bilingualism and migration. Berlin: Mouton. 75-95.

Garrett, P. 2007. „Language socialization and the (re)production of bilingual subjectivities”. W zbiorze: Heller, M. (red.) Bilingualism: a social approach. New York: Palgrave. 233-256.

Garrett, P. i P. Baquedano-López. 2002. „Language socialization: reproduction and continuity, transformation and change". Annual Review of Anthropology 31. 339-361.

Glaser, B. i A. Strauss. 1967. Discovery of grounded theory: strategies for qualitative research. Chicago: Adline. 
Grosjean, F. 2008. Studying bilinguals. Oxford: Oxford University Press.

Grosjean, F. 2010. Bilingual: life and reality. Cambridge: Harvard University Press.

Harding, E. i P. Riley. 1986. The bilingual family. Cambridge: Cambridge University Press.

Labov, W. 1984. Sociolinguistic patterns. Philadelphia: University of Pennsylvania Press.

Lambert, W. 1977. „The effects of bilingualism on the individual: cognitive and sociocultural consequences" W zbiorze: Hornby, P. (red.) Bilingualism: psychological, social and educational implications. New York: Academic Press. 15-28.

Lanza, E. 1990/2004. Language mixing in infant bilingualism: a sociolinguistic perspective. Oxford: Oxford University Press.

Lanza, E. 2007. „Multilingualism and the family”. W zbiorze: Auer, P. i L. Wei (red.) Handbook of multilingualism and multilingual communication. Berlin: Mouton. 43-67.

Milroy, L. i M. Gordon. 2003. Sociolinguistics: method and interpretation. Oxford: Blackwell.

Paradis, J. 2007. „Early bilingual and multilingual acquisition”. W zbiorze: Auer, P. i L. Wei (red.). Handbook of multilingualism and multilingual communication. Berlin: Mouton. 15-44.

Piller, I. 2002. Bilingual couples talk: the discursive construction of hybridity. Amsterdam: John Benjamins.

Quay, S. 2001. „Managing linguistic boundaries in early trilingual development”. W zbiorze: Cenoz, J. i F. Genesee (red.). Trends in bilingual acquisition. Amsterdam: Benjamins. 149-199.

Romaine, S. 1999. „Early bilingual development: from elite to folk”. W zbiorze: Extra, G. i L. Verhoeven (red.). Bilingualism and migration. Berlin: Mouton. 61-73.

Romaine, S. 2008. Bilingualism. Oxford: Blackwell. 